\title{
Effects of Quercetin and Omega-3 Combination on Nuclear Factor Kappa B (NFkB) Expression Level in Pancreatic Tissue of Rats with Type-2 Diabetes Mellitus
}

\author{
Asri Hendrawati ${ }^{*}$ and Mujiyanto Winardi
}

Departement of Biochemistry, Faculty of Medicine, Universitas Islam Indonesia, Sleman, Yogyakarta, Indonesia

Abstract: Background: Hyperglycemia increases nuclear factor kappa B (NFKB) expression and promotes cellular injury.
Quercetin and omega-3 are expected to regulate NFKB expression. This study aims to measure the effect of combination
therapy with quercetin and omega-3 in lowering the expression of NFKB in the pancreatic tissue of rats with type-2 DM
as compared to those treated with monotherapy with either agent.
Methods: This experimental study involved the use of a paraffin block of pancreatic tissue from 24 male Wistar rats aged
3 months, weighing between $250 \mathrm{~g}$ and $350 \mathrm{~g}$. All rats underwent induction of type-2 DM and were divided into 4 groups:
$\mathrm{K} 1$ (treated daily with placebo), K2 (treated with quercetin at $20 \mathrm{mg} \cdot \mathrm{kgBW}^{-1} \cdot \mathrm{d}^{-1}$ ), K3 (treated with omega-3 at 100
$\mathrm{mg} \cdot \mathrm{kgBW}^{-1} \cdot \mathrm{d}^{-1}$ ), and K4 (treated with quercetin at $20 \mathrm{mg} \cdot \mathrm{kgBW}^{-1} \cdot \mathrm{d}^{-1}$ and omega-3 at $100 \mathrm{mg} \cdot \mathrm{kgBW}^{-1} \cdot \mathrm{d}^{-1}$ ). Treatments
were administered orally for four weeks. Once the treatment was completed, samples of pancreatic tissue were collected
for the measurement of the percentage of NFKB expression using immunohistochemical (IHC) staining.

Results: The average level of NFKB expression in the pancreatic nuclei of DM rats treated with the combination of omega-3 and quercetin was significantly lower than that of those treated with placebo, quercetin only, or omega-3 only ( $p$ $<0.05)$.

Conclusion: The combination of quercetin at $20 \mathrm{mg} \cdot \mathrm{kgBW}^{-1} \cdot \mathrm{d}^{-1}$ and omega- 3 at $100 \mathrm{mg} \cdot \mathrm{kgBW}^{-1} \cdot \mathrm{d}^{-1}$ is significantly more effective in lowering the percentage of NFKB in pancreatic nuclei than monotherapy with either agent.

Keywords: Quercetin, omega-3, type-2 diabetes mellitus, immunohistochemistry, nuclear factor kappa B (NFKB).

\section{INTRODUCTION}

Diabetes mellitus (DM) is a chronic acquired hyperglicemia which affects every system in the body as a result of the interaction between the environment and genetic factors [1]. The main sign of type-2 DM is the presence of insulin resistence which causes chronic hyperglycemia. Hyperglicemia leads to increased production of free radicals, especially reactive oxygen species (ROS), in all tissues owing to autooxidation of glucose and glycosylation of protein. In chronic hyperglicemia, there is an imbalance between ROS and antioxidant-mediated cell defense. The state of DM also interferes with lipid metabolism, as evidenced by the increase in lipid peroxidation which results in increased oxidative stress. The increase in oxidative stress plays an important role in the development of atherosclerotic diseases and complications such as cardiomiopathy and heart failure. Furthermore, the increasing levels of free radicals destroy pancreatic $\beta$-cells which will result in reduction in insulin production, increasing the severity of the existing hyperglycemia [2].

*Address correspondence to this author at the Department of Biochemistry, Faculty of Medicine, Universitas Islam Indonesia, Jl. Kaliurang km 14.5 Sleman, Yogyakarta, Indonesia; Tel: +6281329973493;

E-mail: asri_xabi@yahoo.com
In type-2 diabetes mellitus, chronic hyperglycemia increases the levels of advanced glycation end products (AGEs) thus it will bind to receptor for advanced glycation end-products (RAGE). Evidence from various studies shows that AGEs are involved in inflammatory processes, ROS development, and production of AGE. Receptor for AGE interaction with ligands activates various pathways, including oncogene protein p21(ras) (p21ras), extracellular signalregulated kinases (Erk) 1/2, mitogen-activated protein kinase (MAPK), and stress activated protein kinase/Jun $\mathrm{N}$-terminal kinase (SAPK/JNK) MAP kinase. The activation of these pathways results in the translocation of nuclear factor kappa $B$ (NFKB). Translocation of $N F K B$ to the nucleus increases the transcription of various proteins (i.e. vascular endothelial growth factor (VEGF), monocyte chemoattractant protein-1 (MCP-1), vascular cell adhesion molecule-1 (VCAM), and intracellular adhesion molecule-1 (ICAM-1), as well as proinflammatory cytokines (i.e. interleukin (IL) $-1 \beta$, IL-6, $\mathrm{IL}-18$, and tumor necrosis factor (TNF)- $\alpha$ which have damaging effects on various cells in various organs, including pancreas, resulting in the development of complications in type-2 DM [3].

Currently, antihyperglycemic drugs remained the principal therapy for the management of type-2 DM.

(c) 2017 Lifescience Global 
According to previous studies, the use of antihyperglycemic drugs alone is less effective in reducing oxidative stress and free radicals than its use in combination with antioxidants [4]. Management of DM which only aims to lower blood glucose level is less effective in preventing complications than a management modality which aims to lower blood glucose level and oxidative stress [5].

Previous studies show that long-term use of a single antihyperglicemic drug may result in various side effects, e.g. obesity [6]. Intensive therapy using insulin or sulfonylureas are shown to cause weight gain in DM patients. The use of hypoglycemic drugs may also result in death due to severe hypoglycemia [7].

The inclusion of antioxidants in the management of DM has several advantages. Antioxidants can reduce glucotoxicity caused by oxidative stress and, in turn, prevent pancreatic $\beta$-cell injury and regulate glucose metabolism [8]. Flavanoids, such as quercetin, are proven to prevent hepatic cell death in DM-induced rats and can enhance the cellular defense mechanism by increasing the production and activity of antioxidative enzymes, such as catalase and heme oxygenase (HO)-1, resulting in the reduction of oxidative stress caused by free radicals [9].

Quercetin has been proven to lower blood glucose level, normalise the result of oral glucose tolerance test, and increase the function and activity of pancreatic $\beta$-cells [10]. Quercetin is also found to protect rats with streptozotocin (STZ)-induced DM from nerve-tissue injury and decreased kidney function. Administration of quercetin for 30 days plays an important role in reducing diabetic neuropathy and neuropathic pain in rats with STZ-induced DM [11]. Administration of quercetin in DM patients can also reduce inflammatory reaction [10].

DM patients tend to fall in dyslipidemic state and, thus, require attention for the prevention of consequent cardiovascular diseases [12]. Omega-3 is known to have an antiatherogenic effect and improves the results of the lipid profile test. Its atherogenic effect is also obtained through its ability to produce substances which inhibit the formation of thrombus, lowering the risk of cardiovascular diseases in dyslipidemia [13]. Omega-3 also reduces NFKB expression and the production of inflammatory mediators, such as TNFa, interleukin-1, and interleukin-6, as well as inhibits the apoptosis of pancreatic $\beta$-cell through the activity of caspase-3 [14]. Combination therapy with quercetin and omega- 3 is expected to be more effective in lowering the expression of $\mathrm{NFKB}_{\mathrm{K}}$ in the pancreatic tissue of DM patients than monotherapy with either agent to reduce cellular injury and prevent complications of DM; combination therapy will become an important therapy for DM patients in the future. The aim of this research is to study the potential of the combination of quercetin and omega- 3 in lowering the expression of NFKB in pancreatic tissue of rats with type-2 DM as compared to those treated with monotherapy.

\section{MATERIAL AND METHODS}

This study and the experimental protocols were approved by The Ethical Comittee of Medical and Health Research Faculty of Medicine Universitas Islam Indonesia with registration number 37/ka.Kom.Et/70/KE/IV/2016. This study used paraffin block of pancreatic tissue from 24 male Wistar rats aged 3 months and weighing between $250 \mathrm{~g}$ and 350 g. Type-2 DM state was induced in all rates through intraperitoneal administration of single-dose streptozotocin at $60 \mathrm{mg} / \mathrm{kgBW}$ and intraperitoneal administration of single-dose nicotinamide at 120 $\mathrm{mg} / \mathrm{kgBW}$ [15]. One week after the induction, the fasting blood glucose level of these rats were checked. Rats with fasting blood glucose level over $126 \mathrm{mg} / \mathrm{dL}$ were labeled as DM rats [15] and divided into 4 groups, each consisting of 6 rats. The grouping system can be seen in Table 1.

Table 1: Division of Intervention Groups

\begin{tabular}{|c|c|}
\hline $\begin{array}{c}\text { Group } \\
\text { name }\end{array}$ & Description \\
\hline \hline $\mathrm{K} 1$ & DM rats treated daily with placebo \\
\hline $\mathrm{K} 2$ & DM rats treated with quercetin at $20 \mathrm{mg} \cdot \mathrm{kgBW}^{-1} \cdot \mathrm{d}^{-1}$ \\
\hline $\mathrm{K} 3$ & $\mathrm{DM}$ rats treated with omega-3 at $100 \mathrm{mg} \cdot \mathrm{kgBW}^{-1} \cdot \mathrm{d}^{-1}$ \\
\hline $\mathrm{K} 4$ & $\begin{array}{r}\text { DM rats treated with quercetin at } 20 \mathrm{mg} \cdot \mathrm{kgBW}^{-1} \cdot \mathrm{d}^{-1} \\
\text { and omega-3 at } 100 \mathrm{mg} \cdot \mathrm{kgW}^{-1} \cdot \mathrm{d}^{-1}\end{array}$ \\
\hline
\end{tabular}

After four-week oral administration of quercetin and/or omega-3, all rats were euthanized using ether inhalation and then decapitated. After that, their pancreatic tissue was taken to prepare paraffin blocks and dyed with immunohistochemical staining. Results from this immunohistochemical staining of pancreatic tissue were observed using light microscope at $40 x$ magnification and photographed using micrographic tools. Preparations stained with anti-NFKB antibody from Abcam $\AA$ from United States of America. The percentage of cells stained with anti-NFKB was subjectively measured in five visual fields of each slide. 
The percentage of NFKB expression was determined by counting the number of cells presenting NFKB and those not presenting NFKB in each slide. The calculation method was showed below:

$\%$ expression $=\frac{\sum \text { cell which expresses NFKB }}{\sum \text { total cell }} \times 100 \%$

The level of NFKB expression in the pancreatic tissue of rats was observed using immunohistochemical (IHC) method. The nucleus of a cell which expresses NFKB will appear brown, while the nucleus of a cell that does not will appear blue. The differences in the level of NFkB expression in pancreatic tissue between groups were tested by One Way ANOVA. The result of immunohistochemical staining of pancreatic tissue with cells that express NFKB in their nuclei as well as those which do not is shown in Figure 1.

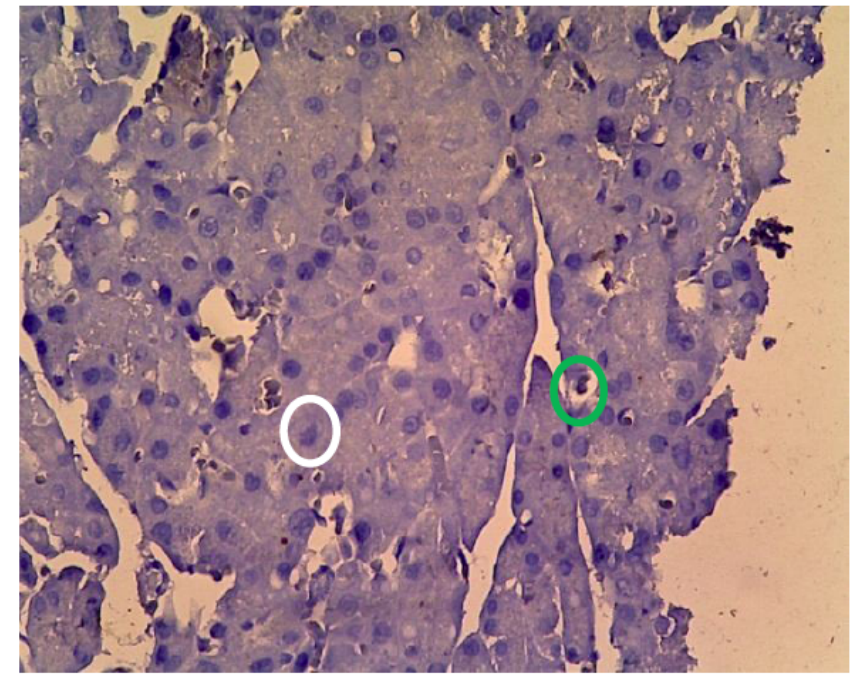

white circle $=$ non-NFkB-expressing nucleus appears in blue, green circle $=$ NFKB-expressing nucleus appears in brown

Figure 1: NFkB-expressing and non-NFKB-expressing pancreatic cells.

\section{RESULTS}

Fasting blood glucose of the groups in this study are eligible so that it can be given treatment until completed. The data of mean fasting blood glucose levels after induction are shown in Table 2.

After the four-week treatment, all rats were decapitated, their pancreas were taken for tissueslicing, and slides were prepared and dyed using immunohistochemical (NFKB) stain. The immunohistochemical staining figures from the 4 groups are shown in Figure 2.
Table 2: Mean Percentage of Fasting Blood Glucose after Induction (\%)

\begin{tabular}{|c|c|}
\hline Group name & Mean fasting blood glucose \\
\hline \hline K1 & $198,83 \pm 6,49$ \\
\hline K2 & $201,16 \pm 7,34$ \\
\hline K3 & $202,75 \pm 7,72$ \\
\hline K4 & $203,31 \pm 8,63$ \\
\hline$P^{*}$ & 0,789 \\
\hline
\end{tabular}

Note: One Way ANOVA test is considered significant if $p$ value is $<0.05$. K1 $\mathrm{DM}$ rats treated daily with placebo, K2: DM rats treated with quercetin at 20 $\mathrm{mg} \cdot \mathrm{kgBW}-1 \cdot \mathrm{d}-1, \mathrm{~K} 3$ : DM rats treated with omega-3 at $100 \mathrm{mg} \cdot \mathrm{kgBW}-1 \cdot \mathrm{d}-1, \mathrm{~K} 4$ : DM rats treated with quercetin at $20 \mathrm{mg} \cdot \mathrm{kgBW}-1 \cdot \mathrm{d}-1$ and omega- 3 at 100 $\mathrm{mg} \cdot \mathrm{kgBW}-1 \cdot \mathrm{d}-1$.

Because the percentage of NFkB expression showed normal distribution and uniform variance in the groups, the difference between groups was tested with One Way ANOVA. The data about the average percentage of NFKB in pancreatic tissue are presented in Table 3.

The results of One Way ANOVA test showed that at least 2 groups had percentages of NFKB which differed significantly $(p<0.05)$. To know which groups had these significantly different percentages of $N F K B$, a post hoc test was conducted using the least significant difference (LSD) test. One Way ANOVA test showed significant differences between NFKB percentage in K1 and that in $\mathrm{K} 2$ to $\mathrm{K} 4$, between NFKB percentage in $\mathrm{K} 2$ and that in $\mathrm{K} 1$ to $\mathrm{K} 4$, between NFKB percentage in $\mathrm{K} 3$ and that in $\mathrm{K} 1$ to $\mathrm{K} 4$, as well as between $\mathrm{NFKB}$ percentage in $\mathrm{K} 4$ and that in $\mathrm{K} 1$ to $\mathrm{K} 3$.

\section{DISCUSSION}

The results of this study showed an increase in NFKB expression in the pancreatic tissue of DM rats as compared to that observed in healthy rats. According to previous studies, NFKB is expressed at a low level in healthy cells, including healthy pancreatic cells [16]. In this study, the researcher observed the level of NFKB expression in the nuclei of pancreatic cells from 6 healthy rats and obtained an average NFKB percentage of $4.44 \pm 0.72$. In the presence of DM, there was an increase in oxidative stress damaging the cells, resulting in an inflammatory response through the activation of NFKB. A previous study showed that the expression of NFKB increases in the presence of hyperglycemia induced in a period of one month to experimental animals [17].

The average level of NFKB expression in the pancreatic nuclei of DM rats that were treated with 

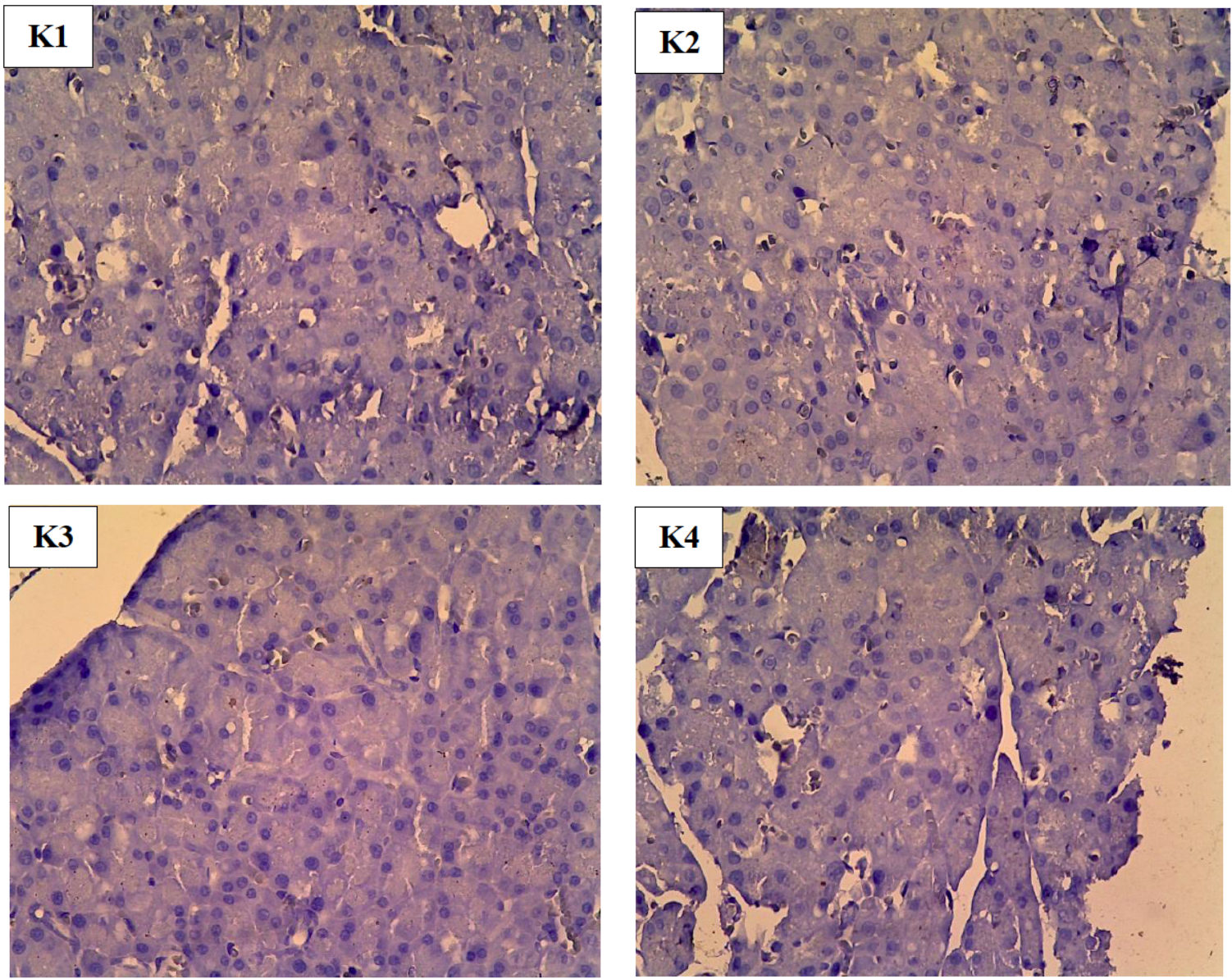

Figure 2: The immunohistochemical staining figures from the 4 groups (K1-K4).

quercetin at $20 \mathrm{mg} \cdot \mathrm{kgBW}^{-1} \cdot \mathrm{d}^{-1}$ for 4 weeks was significantly lower than that of DM rats which were treated with placebo. A previous study showed that quercetin is an antiinflammatoric agent which works by inhibiting the activity of pro-inflammatory cytokines [18]. Another study also showed that quercetin inhibits the activation of $\mathrm{NFKB}$, reducing the production of inflammatoric cytokines [19].

Table 3: Mean Percentage of NFKB in Pancreatic Tissue (\%)

\begin{tabular}{|c|c|c|}
\hline Group name & $\begin{array}{c}\text { Mean percentage of NFKB in } \\
\text { pancreatic tissue (\%) }\end{array}$ & \multirow{2}{*}{$\mathbf{P}^{*}$} \\
\hline \hline K1 & $16.12 \pm 1.17$ & \multirow{2}{*}{0.000} \\
\cline { 1 - 2 } K2 & $12.12 \pm 0.88$ & \\
\hline K3 & $9.99 \pm 0.87$ & \\
\hline K4 & $8.02 \pm 2.34$ & \\
\hline
\end{tabular}

Note: One Way ANOVA test is considered significant if $p$ value is $<0.05$. K1: DM rats treated daily with placebo, K2: DM rats treated with quercetin at 20 $\mathrm{mg} \cdot \mathrm{kgBW}^{-1} \cdot \mathrm{d}^{-1}, \mathrm{~K} 3$ : DM rats treated with omega-3 at $100 \mathrm{mg} \cdot \mathrm{kgBW}^{-1} \cdot \mathrm{d}^{-1}, \mathrm{~K} 4$ : DM rats treated with quercetin at $20 \mathrm{mg} \cdot \mathrm{kgBW}^{-1} \cdot \mathrm{d}^{-1}$ and omega-3 at 100 $\mathrm{mg} \cdot \mathrm{kgBW}^{-1} \cdot \mathrm{d}^{-1}$.

In this study, the average level of NFKB expression in the pancreatic nuclei of DM rats which were treated with omega-3 at $100 \mathrm{mg} \cdot \mathrm{kgBW}^{-1} \cdot \mathrm{d}^{-1}$ for 4 weeks was found to be significantly lower than that of DM rats treated with placebo or with quercetin at $20 \mathrm{mg} \cdot \mathrm{kgBW}^{-}$ ${ }^{1} \cdot d^{-1}$. This finding is in line with that of a research stating that omega-3 lowers the expression of NFKB by inhibiting the activation of NFKB [20]. Another study states that omega-3 increases the activity of PPAR $\mathrm{Y}$, and as PPAR $Y$ binds to NFKB, the translocation of $N F K B$ to the nucleus is prevented and its activation is inhibited [21].

In this study, the average level of NFKB expression in the pancreatic nuclei of DM rats which were treated with quercetin at $20 \mathrm{mg} \cdot \mathrm{kgBW}^{-1} \cdot \mathrm{d}^{-1}$ and omega-3 at $100 \mathrm{mg} \cdot \mathrm{kgBW}^{-1} \cdot \mathrm{d}^{-1}$ for 4 weeks was also found to be significantly lower than that of DM rats treated with placebo, quercetin only, or omega-3 only. This result shows that a combination of quercetin and omega- 3 is more effective in inhibiting the activity of NFKB than monotherapy with either agent. Therefore, the combination of quercetin and omega 3 is more effective and recommended for the treatment of diabetes mellitus in the future because it can reduce the inflammation better than without combination. 


\section{CONCLUSION}

The combination of quercetin at $20 \mathrm{mg} \cdot \mathrm{kgBW}^{-1} \cdot \mathrm{d}^{-1}$ and omega-3 at $100 \mathrm{mg} \cdot \mathrm{kgBW}^{-1} \cdot \mathrm{d}^{-1}$ is significantly more effective in lowering the percentage of NFKB in pancreatic nuclei than monotherapy with either agent.

\section{ACKNOWLEDGEMENT}

The author would like to express her gratitude to the Unit Penelitian dan Pengabdian Masyarakat (UPPM) Faculty of Medicine, Universitas Islam Indonesia for their financial support to fund this research.

\section{CONFLICT OF INTEREST DISCLOSURES}

The author does not have any conflicts of interest.

\section{REFERENCES}

[1] World Health Organization. Global report on diabetes. Geneva; 2016: available on http://www.who.int.

[2] Moussa S. Oxidative stress in diabetes mellitus. Rom J Biophys 2008; 18(3): 225-36.

[3] Ayepola OR, Brooks NL, Oguntibeju OO. Oxidative stress and diabetic complications: the role of antioxidant vitamins and flavonoids. In: Antioxidant-antidiabetic agents and human health. Rijeka, Croatia: INTECH 2014.

[4] Karasu C. Glycoxidative stress and cardiovascular complications in experimentally-induced diabetes: effects of antioxidant treatment. Open Cardiovasc Med J 2010; 4: 24056.

https://doi.org/10.2174/1874192401004010240

[5] Erejuwa OO. Management of diabetes mellitus: could simultaneous targeting of hyperglycemia and oxidative stress be a better panacea? Int J Mol Sci 2012; 13(3): 2965-72. https://doi.org/10.3390/ijms13032965

[6] Ingle PV, Talele GS. Adverse effects of metformin in combination with glimepiride and glibenclamide in patients with type 2 diabetes mellitus. Asian J Pharm Clin Res 2012; 5(Suppl 1): 108-110.

[7] Cryer PE. Death during intensive glycemic therapy of diabetes: mechanisms and implications. Am J Med 2011; 124(11): 993-6.

https://doi.org/10.1016/j.amjmed.2011.08.008

[8] Kajimoto $\mathrm{Y}$, Kaneto $\mathrm{H}$. Role of oxidative stress in pancreatic beta-cell dysfunction. Ann N Y Acad Sci 2004; 1011: 168-76. https://doi.org/10.1196/annals.1293.017

[9] Parabathina RK, Raja GV, Rao MN, Rao GS, Rao KS. Cardioprotective effects of vitamin E, morin, rutin and quercetin against doxorubicin induced oxidative stress of rabbits: a biochemical study. J Chem Pharm Res 2010; 2(3): 754-65.
[10] Kelly GS. Quercetin. Monograph. Altern Med Rev 2011; 16(2): 172-94.

[11] Anjaneyulu M, Chopra K. Quercetin, an anti-oxidant bioflavonoid, attenuates diabetic nephropathy in rats. Clin Exp Pharmacol Physiol 2004; 31(4): 244-8. https://doi.org/10.1111/j.1440-1681.2004.03982.x

[12] Bardini G, Rotella CM, Giannini S. Dyslipidemia and diabetes: reciprocal impact of impaired lipid metabolism and beta-cell dysfunction on micro- and macrovascular complications. Rev Diabet Stud 2012; 9(2-3): 82-93. https://doi.org/10.1900/RDS.2012.9.82

[13] Wardlaw G, Hampl J. Perspectives in nutrition 7th ed. New York: McGraw Hill 2007.

[14] Fayez AM, Awad AS, El-Naa MM, Kenawy SA, El-Sayed ME. Beneficial effects of thymoquinone and omega-3 on intestinal ischemia/reperfusion-induced renal dysfunction in rats. Bull Fac Pharmacy, Cairo Univ 2014; 52(2): 171-7. https://doi.org/10.1016/j.bfopcu.2014.05.003

[15] Barik R, Jain S, Qwatra D, Joshi A, Tripathi G, Goyal R. Antidiabetic activity of aqueous root extract of Ichnocarpus frutescens in streptozotocin-nicotinamide induced type-II diabetes in rats. Indian J Pharmacol 2008; 40(1): 19. https://doi.org/10.4103/0253-7613.40484

[16] Pham NA, Schwock J, lakovlev V, Pond G, Hedley DW, Tsao MS. Immunohistochemical analysis of changes in signaling pathway activation downstream of growth factor receptors in pancreatic duct cell carcinogenesis. BMC Cancer 2008; 8(1): 43.

https://doi.org/10.1186/1471-2407-8-43

[17] Starkey JM, Haidacher SJ, LeJeune WS, Zhang X, Tieu BC Choudhary $\mathrm{S}$, et al. Diabetes-induced activation of canonical and noncanonical nuclear factor-kappaB pathways in renal cortex. Diabetes 2006; 55(5): 1252-9.

https://doi.org/10.2337/db05-1554

[18] Bischoff SC. Quercetin: potentials in the prevention and therapy of disease. Curr Opin Clin Nutr Metab Care 2008; 11(6): 733-40. https://doi.org/10.1097/MCO.0b013e32831394b8

[19] Indra M, Karyono S, Ratnawati R, Malik SG. Quercetin suppresses inflammation by reducing ERK1/2 phosphorylation and NF kappa B activation in leptin-induced human umbilical vein endothelial cells (HUVECs). BMC Res Notes 2013; 6(1): 275 https://doi.org/10.1186/1756-0500-6-275

[20] Zwart SR, Pierson D, Mehta S, Gonda S, Smith SM Capacity of omega-3 fatty acids or eicosapentaenoic acid to counteract weightlessness-induced bone loss by inhibiting NF-kB activation: from cells to bed rest to astronauts. J Bone Miner Res 2009; 25(5): 1049-57. https://doi.org/10.1359/jbmr.091041

[21] Vanden BW, Vermeulen L, Delerive $P$, De Bosscher $K$, Staels B, Haegeman G. A paradigm for gene regulation: inflammation, NF-kappaB and PPAR. Adv Exp Med Biol 2003; 544: 181-96.

https://doi.org/10.1007/978-1-4419-9072-3 22

\section{DOI: https://doi.org/10.6000/1927-5951.2017.07.01.1}

(c) 2017 Hendrawati and Winardi; Licensee Lifescience Global.

This is an open access article licensed under the terms of the Creative Commons Attribution Non-Commercial License (http://creativecommons.org/licenses/by-nc/3.0/) which permits unrestricted, non-commercial use, distribution and reproduction in any medium, provided the work is properly cited. 